\title{
Acetylsalicylic Acid and Morphology of Red Blood Cells
}

\author{
Jacques Natan Grinapel Frydman ${ }^{1,2}$, Adenilson de Souza da Fonseca ${ }^{2 *}$, Vanessa Câmara da \\ Rocha $^{2}$, Monica Oliveira Benarroz ${ }^{1,2}$, Gabrielle de Souza Rocha ${ }^{1,2}$, Marcia de Oliveira \\ Pereira $^{1,2}$, Mario José Pereira ${ }^{3}$, Aldo Cunha Medeiros ${ }^{1,4}$ and Mario Bernardo-Filho ${ }^{2}$ \\ ${ }^{I}$ Programa de Pós-Graduação em Ciências da Saúde; Universidade Federal do Rio Grande do Norte; Avenida Nilo \\ Peçanha, s/n; 59012300; Natal - RN - Brasil. ${ }^{2}$ Departamento de Biofísica e Biometria; ${ }^{3}$ Departamento de \\ Fisiologia; Instituto de Biologia Roberto Alcantara Gomes; Universidade do Estado do Rio de Janeiro; Avenida 28 \\ de Setembro, 87; 20551030; Rio de Janeiro - RJ - Brasil. ${ }^{4}$ Departamento de Cirurgia; Universidade Federal do Rio \\ Grande do Norte; Avenida Nilo Peçanha, s/n; 59012300; Natal - RN - Brasil.
}

\begin{abstract}
This work evaluated the effect of in vitro and in vivo treatment with ASA on the morphology of the red blood cells. Blood samples or Wistar rats were treated with ASA for one hour. Blood samples or animals treated with saline were used as control group. Blood smears were prepared, fixed, stained and the qualitative and quantitative morphology of red blood cells were evaluated under optical microscopy. Data showed that the in vitro treatment for one hour with ASA at higher dose used significantly $(p<0.05)$ modified the perimeter/area ratio of the red blood cells. No morphological alterations were obtained with the in vivo treatment. ASA use at highest doses could interfere on shape of red blood cells.
\end{abstract}

Key words: Acetylsalicylic Acid; Blood Cells; Morphology

\section{INTRODUCTION}

Acetylsalicylic acid is a classical nonsteroidal antipyretic, analgesic and anti-inflammatory drug and in the United States alone, 35,000 kg are consumed daily (Jack, 1997). Its actions are based on irreversible inhibition of cyclooxygenases 1 and 2 that are responsible for the prostaglandin synthesis and some autacoids (Catella-Lawson, 2001; Amann and Peskar, 2002; Aude and Mehta, 2002). The anti-thrombotic action of acetylsalicylic acid is mainly due to its antiplatelet action (Grotta et al., 1985; Catella-Lawson, 2001; Insel, 2001) but it has been postulated that the inhibition of oxidative stress could be related to the ability of this drug to prevent cerebrovascular accidents (Sagone and Husney, 1987; Guerrero et al., 2004). On the other hand, acetylsalicylic acid at therapeutic doses could induce the gastrointestinal adverse effects as gastric ulcer, erosive gastritis, gastrointestinal hemorrhage and exacerbation of peptic ulcer symptoms (Bollini et al., 1992), as well as ions imbalance associated to respiratory alkalosis with increased $\mathrm{Na}^{+}, \mathrm{K}^{+}$and bicarbonate excretion (Lauwerys and Bernard, 1989; Nuyts et al., 1989).

Morphometric analysis has been used to evaluate the morphological changes induced in different cellular systems: (i) chronic ocular hypertensive effects on thickness of retinal nerve fiber layer and optic disc structure (Shimazawa et al., 2006), (ii) relationship between infarct-related artery stenosis and capillary density (Prech et al., 2006), and (iii) effects of sexual hormones on mamma gland

\footnotetext{
*Author for correspondence: adenilso@uerj.br
} 
(Pompei et al., 2005). Red blood cells have been proposed as a prototypical cellular system regarding drug mediated plasma membrane effects (Li et al., 1999). Different techniques have demonstrated that therapeutic drugs can modify the structure and morphology of these cells (Nwafor and Coakley, 1986; Scheiman and Elta, 1990; Li et al., 1999; Shacter and Weitzman, 2002; Suwalsky et al., 2003; Hubner et al., 2005; Santos et al., 2005; Zhang et al., 2005). The morphometric analysis (area, shape and volume measurements) has been used to evaluate the alterations induced by natural products and synthetic drugs on membrane of red blood cells (Oliveira et al., 2002; Moreno et al., 2004).

The aim of this work was to evaluate the effect of in vitro and in vivo treatment with acetylsalicylic acid on the morphology of the red blood cells.

\section{MATERIAL AND METHODS}

\section{Animals}

Adult male Wistar naive rats (3-4 month of age, body weight $250-350 \mathrm{~g}$ ) were housed, five per cage, in an environmental controlled room. Animals had free access to water and food and ambient temperature was kept at $25 \pm 2^{\circ} \mathrm{C}$. Experiments were conducted in accordance with the Department Committee of Animal Care.

\section{Drugs}

Commercial acetylsalicylic acid used in this study was purchased from Bayer (Aspirin $\AA$, Brazil).

\section{In vitro treatment with acetylsalicylic acid}

Samples of heparinized whole blood were treated for one hour with acetylsalicylic acid at different doses $(0.01,0.10$ and $1.00 \mathrm{mg} / \mathrm{mL})$. Blood samples treated with $0.9 \% \mathrm{NaCl}$ were used as control group. These concentrations were similar to the plasma levels in humans under antiinflammatory therapy with this drug (Insel, 2001).

\section{In vivo treatment with acetylsalicylic acid}

Wistar rats $(\mathrm{n}=9)$ were treated for one hour with acetylsalicylic acid at different doses (1.5, 3.0 and $6.0 \mathrm{mg} / \mathrm{kg}$, intragastric adminstration) and after heparinized, whole blood was withdrawn. Animals $(n=10)$ treated with saline solution $(0.9 \% \mathrm{NaCl}$, intragastric administration) were used as control group. These doses were similar to that used in antiinflammatory therapy with this drug (Insel, 2001) and experimental investigations (Guerrero et al., 2004).

\section{Morphological evaluation of red blood cells}

Histological preparations were carried out with blood samples in vitro or in vivo treated with acetylsalicylic acid for one hour at room temperature, or with $\mathrm{NaCl}(0.9 \%)$ as control group. Blood smears were prepared, dried, fixed and stained by May-Grünwald-Giensa method (Junqueira and Carneiro, 2002). After that, the images of red blood cells were acquired (Optronics, Japan) from blood smears under optical microscopy (x1000). For the morphometric analysis of red blood cells, the perimeter/area ratio was obtained from images by specific program (Image ProPlus Software). Morphological analyses were carried out by blind way by a specialist in histological analysis.

\section{Statistical analysis}

Data are reported as means \pm SD of perimeter/area ratio. They were compared between the treated and control group by one way analysis of variance (ANOVA), followed by Bonferroni post test with a $p<0.05$ as significant level. InStat Graphpad software was used to perform the statistical analysis (GraphPad InStat version 3.00 for Windows 95, GraphPad Software, San Diego California, USA).

\section{RESULTS}

Figs. 1 and 2 show the photomicrographs of the blood smears from blood in vitro treated with $0.9 \% \mathrm{NaCl}$ solution (control) and with acetylsalicylic acid at the highest concentration used $(1.0 \mathrm{mg} / \mathrm{mL})$, respectively. The qualitative morphological analysis by the comparison between these figures showed that the acetylsalicylic acid induced major changes on the shape of the red blood cells.

Fig. 3 shows the perimeter/area ratio for red blood cells from blood samples in vitro treated with acetylsalicylic acid at different concentrations. The analysis of these data indicated that acetylsalicylic acid significantly $(p=0.014)$ modified the perimeter/area ratio of red blood cells at the higher concentration used. 


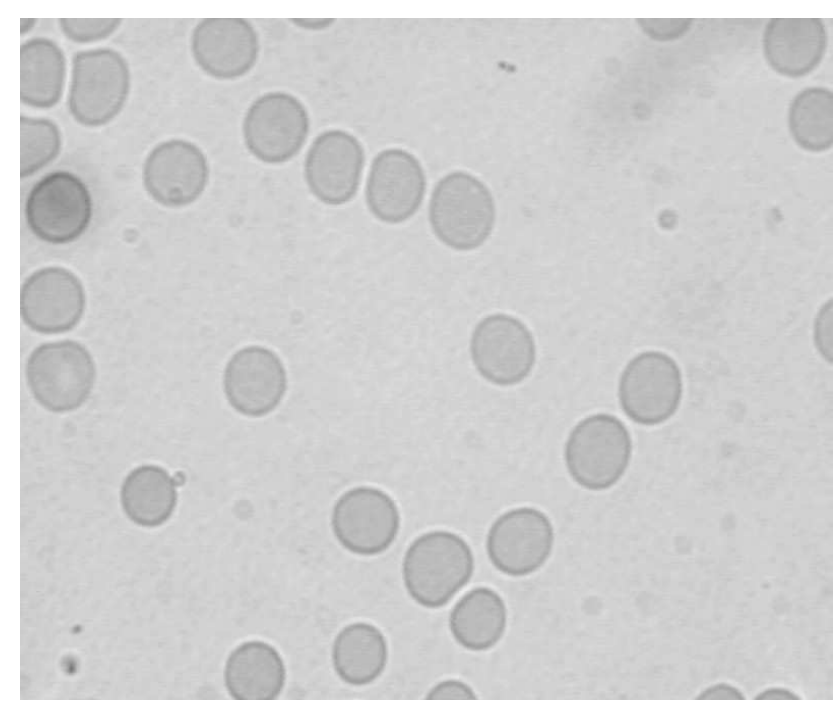

Figure 1 - Photomicrography of blood smears from blood samples in vitro treated with $0.9 \% \mathrm{NaCl}$ solution (control group). Samples of whole blood from Wistar rats were treated with $0.9 \%$ $\mathrm{NaCl}$ solution during 60 minutes. Blood smears were prepared, dried, fixed and staining by May-Grünwald-Giensa method. The morphology of red blood cells was evaluated under optical microscopy (x1000) after image capture.

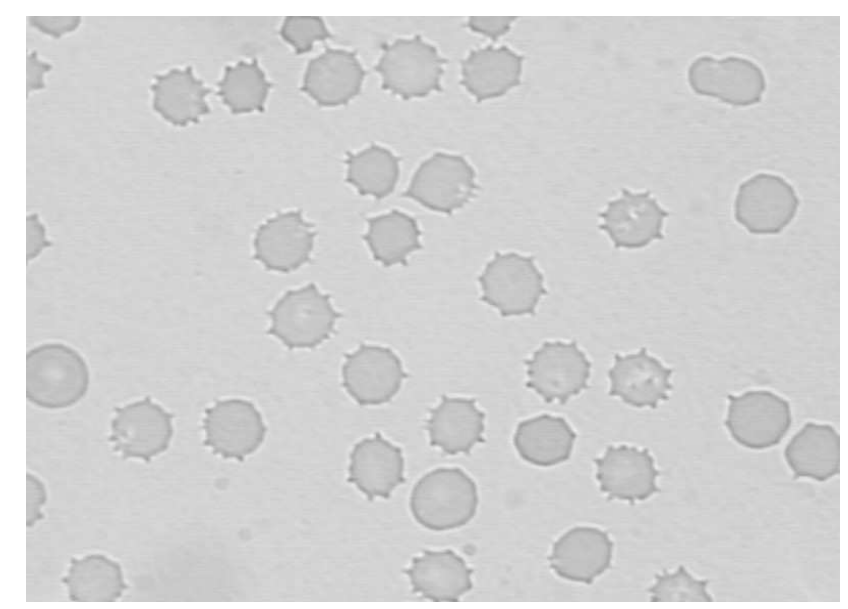

Figure 2 - Photomicrography of blood smears from blood samples in vitro treated with acetylsalicylic acid. Samples of whole blood from Wistar rats were treated with acetylsalicylic acid (1.0 $\mathrm{mg} / \mathrm{mL}$ ) during 60 minutes. Blood smears were prepared, dried, fixed and staining by May-Grünwald-Giensa method. The morphology of red blood cells was evaluated under optical microscopy (x1000) after image capture. 


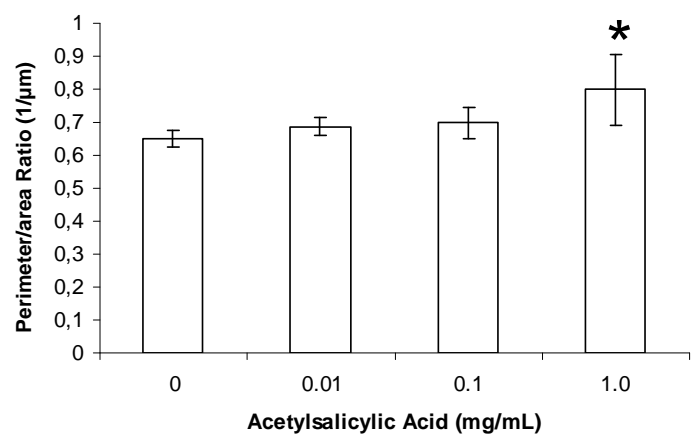

Figure 3 - Effects of acetylsalicylic acid on the perimeter/area ratio of red blood cells from blood in vitro treated. Samples of whole blood from Wistar rats were treated with acetylsalicylic acid at different concentrations during 60 minutes. Blood smears were prepared, dried, fixed and staining by May-Grünwald-Giensa method. The morphology of red blood cells was evaluated under optical microscopy (x1000) after image captures of five fields for each smear and five smears for each acetylsalicylic acid concentration. After that, morphometric measurements (perimeter and area) were carried out and perimeter/area calculated.

Figs. 4 and 5 show the photomicrographs of the blood smears from blood in vivo treated with $0.9 \%$ $\mathrm{NaCl}$ solution (control) and with acetylsalicylic acid at the highest dose used (6 $\mathrm{mg} / \mathrm{kg})$, respectively. The qualitative morphological analysis by the comparison between these figures shown that the in vivo acetylsalicylic acid did not induce any significant modifications in the shape of the red blood cells.

Fig. 6 shows the perimeter/area ratio for red blood cells from blood samples in vivo treated with acetylsalicylic acid at different doses. The analysis of these data indicated that in vivo acetylsalicylic acid did not alter significantly $(p=0.749)$ the perimeter/area ratio of red blood cells.

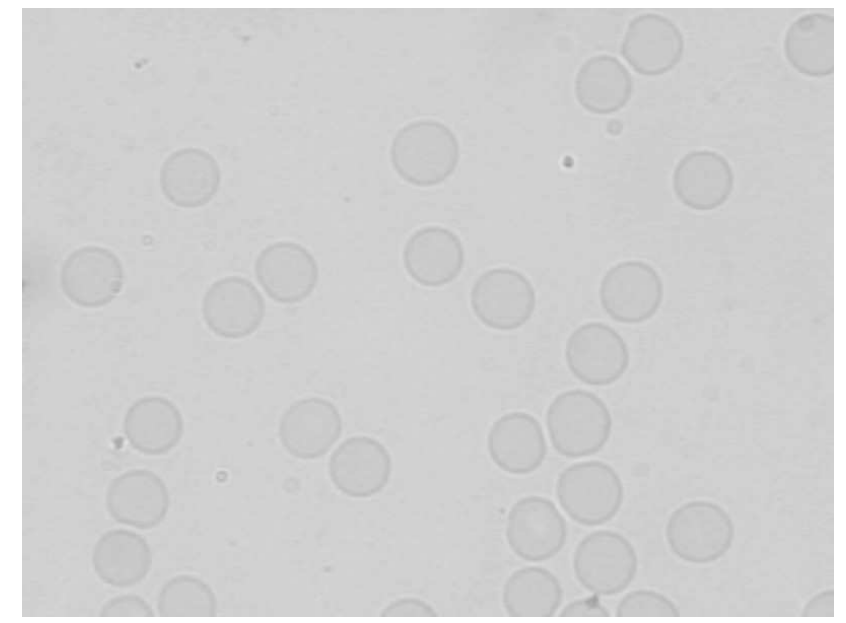

Figure 4 - Photomicrography of blood smears from blood samples in vivo treated with $0.9 \% \mathrm{NaCl}$ solution (control group). Wistar rats were treated with $\mathrm{NaCl} 0.9 \%$ solution during 60 minutes. After that, blood samples were withdraw, blood smears were prepared, dried, fixed and staining by May-Grünwald-Giensa method. The morphology of red blood cells was evaluated under optical microscopy (x1000) after image capture. 


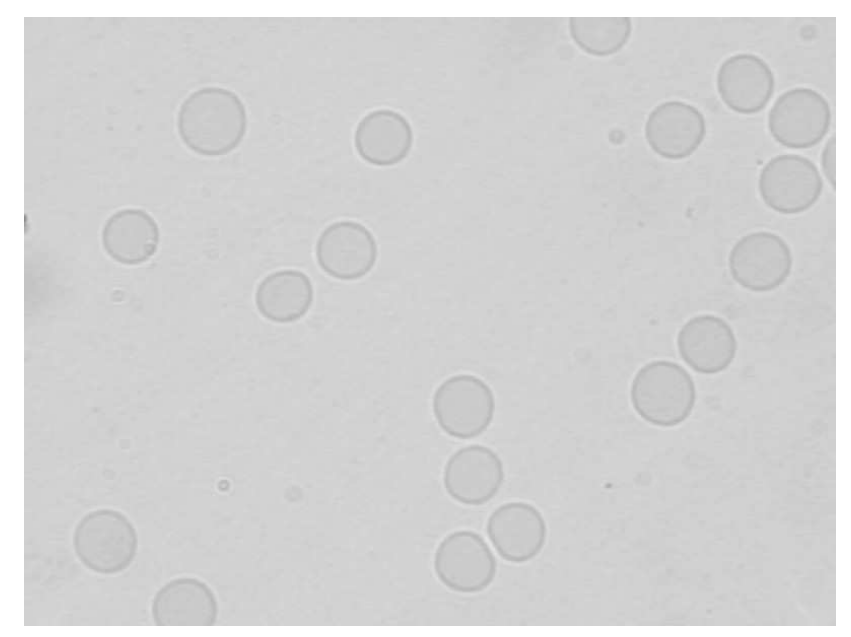

Figure 5 - Photomicrography of blood smears from blood samples in vivo treated with acetylsalicylic acid. Wistar rats were treated with acetylsalicylic acid $(6.0 \mathrm{mg} / \mathrm{kg})$ during 60 minutes. After that, blood samples were withdraw, blood smears were prepared, dried, fixed and staining by May-Grünwald-Giensa method. The morphology of red blood cells was evaluated under optical microscopy (x1000) after image capture.

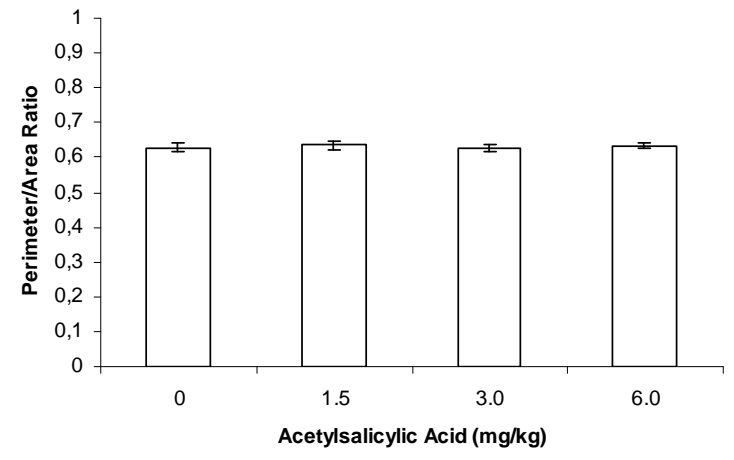

Figure 6 - Effects of acetylsalicylic acid on the perimeter/area ratio of red blood cells from blood in vivo treated. istar rats were treated with acetylsalicylic acid at different concentrations during 60 minutes. After that, blood samples were withdraw, blood smears were prepared, dried, fixed and staining by May-Grünwald-Giensa method. The morphology of red blood cells was evaluated under optical microscopy (x1000) after image captures of five fields for each smear and five smears for each acetylsalicylic acid concentration. After that, morphometric measurements (perimeter and area) were carried out and perimeter/area calculated.

\section{DISCUSSION}

The data obtained in this work showed that in vitro or in vivo acetylsalicylic acid did not affect the morphology of red blood cells at doses similar to used in anti-thrombotic, antipyretic or anti- inflammatory therapy (Figs. 3, 5 and 6). However, in vitro acetylsalicylic acid at the higher dose (1.0 $\mathrm{mg} / \mathrm{mL}$ ) could alter the morphology of red blood cells as observed by the qualitative analysis and confirmed by the morphometric measurement of perimeter/area ratio (Figs. 2 and 3). 
Different techniques have been used to evaluate the effects of the interaction between the drugs and plasma membrane. Using a photometric method, it was demonstrated that derivates but not acetylsalicylic acid were capable to induce the changes in red blood cell shape (Li et al., 1999). However, an in vitro study showed that acetylsalicylic acid at highest doses could increase the deformability and osmotic fragility of the membrane of red blood cells (Bilto, 1999). By electron spin resonance spectroscopy, it was demonstrated that humans submitted to highest doses of acetylsalicylic acid presented structural changes in the membrane of red blood cells (Mazorow et al., 1985).

It was demonstrated that 30 minutes after a single dose of $0.65 \mathrm{~g}$, only $27 \%$ of acetylsalicylic was in acetylated form due its metabolism in plasma, liver and erythrocytes (Amann and Peskar, 2002). About $50 \%$ of acetylsalicylic acid are deacetylated to salicylate already during and immediately after its absorption (Amann and Peskar, 2002). In this condition, acetylsalicylic acid reaches the detectable plasma level in 30 minutes but the higher plasma concentration occurs only after one hour (Insel, 2001). However, the present data showed that the acetylsalicylic acid concentration reached one hour after in vivo treatment could be low and no alterations on membrane shape was observed. This hypothesis was confirmed by in vitro treatment at high dose $(1.0 \mathrm{mg} / \mathrm{mL})$ where modifications on membrane shape were observed (Fig. 2 and 3).

Acetylsalicylic acid at normal dose $(10 \mathrm{mg} / \mathrm{kg} /$ day $)$ can cause peroxidation in human erythrocytes, increasing glutathione peroxidase and catalase activities but without changing the susceptibility to oxidation (Durak et al., 2001). Other authors reported decrease in glutathione levels in Wistar rats after acetylsalicylic acid treatment at $10 \mathrm{mg} / \mathrm{kg}$ with plasma levels about $10 \mu \mathrm{g} / \mathrm{mL}$ (Guerrero et al., 2004). In fact, it was hypothesized that gastric damage induced by acetylsalicylic acid could be connected with the degradation of the lipid components of the cellular membranes (Javor et al., 1986). Salicylates may cause direct cellular toxicity via inhibition of membrane transport properties (Scheiman and Elta, 1990). Other data have demonstrated that acetylsalicylic acid can alter the inward calcium currents by voltage-gated $\mathrm{Ca}^{+2}$ channels (Greffrath et al., 2002; Kim et al., 2001). Indeed, salicylates uncouple the oxidative phosphorylation, leading diminished cellular ATP concentrations at pharmacological relevant doses (Cronstein et al., 1994). This effect may alter the ions balance ATP-dependent and induce alterations on membrane. These mechanisms could be involved in effects of in vitro acetylsalicylic acid on membrane of red blood cells as observed, in the present work.

In conclusion, acetylsalicylic acid at doses similar to anti-thrombotic, antipyretic, analgesic or antiinflammatory therapy could be not capable but at toxic doses, alterations on membrane of red blood cells could be induced.

\section{RESUMO}

Este trabalho avaliou o efeito do tratamento in vitro e in vivo com AAS na morfologia dos eritrócitos. Amostras de sangue ou ratos Wistar foram tratadas com AAS por uma hora. Amostras sangüíneas ou animais tratados com salina foram utilizados como grupos controle. Distensões de sangue foram preparadas, fixadas, coradas e a análise morfológica qualitativa e quantitativa dos eritrócitos foi realizada em microscópio óptico. Os dados mostraram que o tratamento in vitro por uma hora com AAS na maior dose utilizada modificou significativamente $(\mathrm{p}<0.05)$ a relação perímetro/área dos eritrócitos. Não foram obtidas alterações morfológicas com o tratamento in vivo. $\mathrm{O}$ uso do AAS em doses altas poderia interferir na forma dos eritrócitos.

\section{REFERENCES}

Amann, R., Peskar, B. A. (2002), Anti-inflammatory effects of aspirin and sodium salicylate. Eur. $J$. Pharmacol., 447, 1-9.

Aude, Y. W., Mehta, J. L. (2002), Nonplatelet-mediated effects of aspirin. Drugs Today (Barcelona), 38, 501507.

Bilto, Y. Y. (1999), Rheological action of aspirin on human erythrocytes. Clin. Hemorheol. Micro., 20, 159-165.

Bollini, P., Garcia Rodriguez, L. A., Perez Gutthann, S., Walker, A. M. (1992), The impact of research quality and study design on epidemiologic estimates of the effect of nonsteroidal anti-inflammatory drugs on upper gastrointestinal tract disease. Arch. Intern. Med., 152, 1289-1295.

Catella-Lawson, F. (2001), Vascular biology of thrombosis: platelet-vessel wall interactions and aspirin effects. Neurology, 57 (suppl.), S5-S7. 
Cronstein, B. N., Van de Stouwe, M., Druska, L., Levin, R. I., Weissmann, G. (1994), Nonsteroidal antiinflammatory agents inhibit stimulated neutrophil adhesion to endothelium: adenosine dependent and independent mechanisms. Inflammation, 18, 323-335.

Durak, I., Karaayvaz, M., Cimen, M. Y., Avci, A., Cimen, O. B., Buyukkocak, S., Ozturk, H. S., Ozbek, H., Kacmaz, M. (2001), Aspirin impairs antioxidant system and causes peroxidation in human erythrocytes and guinea pig myocardial tissue. Hum. Exp. Toxicol., 20, 34-37.

Greffrath, W., Kirschstein, T., Nawrath, H., Treede, R. D. (2002), Acetylsalicylic acid reduces heat responses in rat nociceptive primary sensory neurons--evidence for a new mechanism of action. Neurosci. Lett., 320, 61-64.

Grotta, J. C., Lemak, N. A., Gary, H., Fields, W. S., Vital, D. (1985), Does platelet antiaggregant therapy lessen the severity of stroke? Neurology, 35, 632-636.

Guerrero, A., González-Correa, J. A., Arrebola, M. M., Muñoz-Marín, J., Sánchez de La Cuesta, F., De La Cruz, J. P. (2004), Antioxidant effects of a single dose of acetylsalicylic acidand salicylic acid in rat brain slices subjected to oxygen-glucose deprivation in relation with its antiplatelet effect. Neurosci. Lett., 328, 153-156.

Gwyn, K., Sinicrope, F. A. (2002), Chemoprevention of colorectal cancer. Am. J. Gastroenterol., 97, 13-21.

Hubner, Y., Hoettges, K. F., Kass, G. E., Ogin, S. L., Hughes, M. P. (2005), Parallel measurements of drug actions on Erythrocytes by dielectrophoresis, using a three-dimensional electrode design. IEE Proc. Nanobiotechnol., 152, 150-154.

Insel, P. A. (2001), Analgesic-antipyretic and antiinflammatory agents and drugs employed in the treatment of gout. In: Hardman, J. G., Limbird, L. E., Gilman, A. G. (ed) Goodman and Gilman's: The Pharmacological Basis of Therapeutics. McGrawHill, New York.

Jack, D. B. (1997), One hundred years of aspirin. Lancet, 350, 437-439.

Javor, T., Tarnok, F., Past, T., Nagy, S. (1986), Cytoprotective effect of free radical scavengers against mucosal damage produced by different antirheumatic drugs. Int. J. Tissue React., 8, 35-40.

Junqueira, L. C., Carneiro, J. (2002), Basic Histology. $10^{\text {th }}$ ed. McGraw-Hill Medical, New York.

Kim, E. Y., Chang, S. Y., Chung, J. M., Ryu, B. R., Joo, C. K., Moon, H. S., Kang, K., Yoon, S. H., Han, P. L., Gwag, B. J. (2001), Attenuation of Zn2+ neurotoxicity by aspirin: role of N-type $\mathrm{Ca} 2+$ channel and the carboxyl acid group. Neurobiol. Dis., 8, 774783.
Lauwerys, R., Bernard, A. (1989), Preclinical detection of nephrotoxicity: description of the tests and appraisal of their health significance. Toxicol. Lett., 46, 13-29.

Li, A., Seipelt, H., Muller, C., Shi, Y., Artmann, M. (1999), Effects of salicylic acid derivatives on red blood cell membranes. Pharmacol. Toxicol., 85, 206211.

Mazorow, D. L., Haug, A., Bull, R., McGroarty, E. J. (1985), Effects of aspirin, indomethacin, and sodium salicylate on human erythrocyte membranes as detected with electron spin resonance spectroscopy. Thromb. Res., 40, 779-792.

Moreno, S. R. F., Carvalho, J. J., Nascimento, A. L. R., Freitas, R. S., Diré, G. F., Lima, E. A., Lima-Filho, G. L., Rocha, E. K., Bernardo-Filho, M. (2004), Biodistribution of sodium pertechnetate and light microscopy of organs isolated from the rats: study of the effects of a Ginkgo biloba extract. Pakistan J. Nut., 3, 64-67.

Mori, H., Matsunaga, K., Tanakamaru, Y., Kawabata, K., Yamada, Y., Sugie, S., Nishikawa, A. (1999), Effects of protocatechuic acid, Smethylmethanethiosulfonate or 5-hydroxy-4-(2phenyl-(E)ethenyl)-2(5H)-furanone(KYN-54) on 4(methylnitrosamino)-1-(3-pyridyl)-1-butanoneinduced pulmonary carcinogenesis in mice. Cancer Lett., 135, 123-127.

Moyad, M. A. (2001), Review of potential risk factors for kidney (renal cell) cancer. Semin. Urol. Oncol., 19, 280-293.

Nwafor, A., Coakley, W. T. (1986), Chargeindependent effects of drugs on erythrocyte morphology. Biochem. Pharmacol., 35, 953-957.

Nuyts, G. D., Elseviers, M. M., De Broe, M. E. (1989), Health impact of renal disease due to nephrotoxicity. Toxicol. Lett., 46, 31-44.

Oliveira, J. F. Ávila, A. S., Braga, A. C. S., Oliveira, M. B. N., Boasquevisque, E. M., Jales, R. L., Cardoso, V. N., Bernardo-Filho, M. (2002), Effect of extract of medicinal plants on the labeling of blood elements with Technetium-99m and on the morphology of red blood cells: a study with Paullinia cupana. Fitoterapia, 73, 305-312.

Podhaisky, H. P., Abate, A., Polte, T., Oberle, S., Schroder, H. (1997), Aspirin protects endothelial cells from oxidative stress--possible synergism with vitamin E. FEBS Lett., 417, 349-351.

Pompei, L. M., Carvalho, F. M., Ortiz, S. C., Motta, M. C., Cruz, R. J., Melo, N. R. (2005) Morphometric evaluation of effects of two sex steroids on mammary gland of female rats. Maturitas, 5, 370-379. 
Prech, M., Grajek, S., Marszalek, A., Lesiak, M., Jemielity, M., Araszkiewicz, A., Mularek-Kubzdelat, T., Cieslinski, A. (2006), Chronic infarct-related artery occlusion is associated with a reduction in capillary density. Effects on infarct healing. Eur. $J$. Heart Fail., 8, 373-80.

Sagone, A. L., Husney, R. M. (1987), Oxidation of salicylates by stimulated granulocytes: evidence that these drugs act as free radical scavengers in biological systems. J. Immunol., 138, 2177-2183.

Santos, N. C., Martins-Silva, J., Saldanha, C. (2005), Gramicidin D and dithiothreitol effects on erythrocyte exovesiculation. Cell Biochem. Biophys., 43, 419430.

Scheiman, J. M., Elta, G. H. (1990), Gastroduodenal mucosal damage with salsalate versus aspirin: results of experimental models and endoscopic studies in humans. Sem. Arthritis Rheumatism, 20, 121-127.

Shacter, E., Weitzman, S. A. (2002), Chronic inflammation and cancer. Oncology (Williston Park), 16, 217-226.

Shimazawa, M., Taniguchi, T., Sasaoka, M., Hara, H. (2006), Nerve fiber layer measurement using scanning laser polarimetry with fixed corneal compensator in normal cynomolgus monkey eyes. Ophthalmic Res., 38, 1-7.
Suwalsky, M., Hernandez, P. L., Villena, F., Sotomayor, C. P. (2003), The anticancer drug cytarabine does not interact with the human erythrocyte membrane. Z. Naturforschung $C, \mathbf{5 8}, 885-$ 890.

Wu, R., Lamontagne, D., de Champlin, J. (2002), Antioxidative properties of acetylsalicylic acidon vascular tissues from normotensive and spontaneously hypertensive rats. Circulation, 105, 387-392.

Zhang, X., Inukai, T., Hirose, K., Akahane, K., Nemoto, A., Takahashi, K., Sato, H., Kagami, K., Goi, K., Sugita, K., Nakazawa, S. (2005), Induction of impaired membrane phospholipid asymmetry in mature erythrocytes after chemotherapy. Int. J. Hematol., 82, 132-136.
Received: June 14, 2007; Revised: March 13, 2008; Accepted: July 28, 2009. 